\title{
Manufacturing strategy issues in selected Indian manufacturing industry
}

\author{
Mahender Singh $^{a^{*}}$, P.C. Basak ${ }^{b}$ and Rajbir Singh ${ }^{c}$
}

${ }^{a}$ Department of Mechanical Engineering, D.C.R. University of Science and Technology, Murthal-131039 Sonepat, Haryana, India

${ }^{b}$ Professor of Management, Indira Gandhi National Open University New Delhi-110068, India

${ }^{c}$ Professor, Faculty of Management Studies, D.C.R. University of Science and Technology, Murthal-131039 Sonepat, Haryana, India

\section{CHRON I C LE A B S T RAC T}

Article history:

Received August 12, 2012

Received in revised format

30 January 2013

Accepted 30 January 2013

Available online

January 302013

Keywords:

Manufacturing strategy

Competitive priorities

Performance measure

Improvement activities

\begin{abstract}
This paper presents some findings of Indian manufacturing sectors viz. automobile (especially two-wheeler), tractor and general manufacturing industry. Various manufacturing strategy issues such as competitive priorities, improvement activities, and performance measures, have been identified and assessed in Indian context. Sector wise comparison of competitive priorities, improvement activities i.e. advanced manufacturing technology (AMT), integrated information systems (IIS), and advanced management systems (AMS), and performance measure, is provided. Our results show that most of the Indian companies are still emphasizing on quality. However, automobile sector has set to compete globally with high innovation rate, faster new product development, and continuous improvement. It is also observed that Indian companies are investing more in AMS as compared to IIS and AMT. Manufacturing competence index is also computed for each sector.
\end{abstract}

(c) 2013 Growing Science Ltd. All rights reserved.

\section{Introduction}

Manufacturing strategy, a functional strategy, is usually not taken very seriously by the Indian manufacturers till very recently. The reason for this may be ascribed to the lack of competitive business environment along with the various regulatory activities pursued by the government of India. But, the situation has started changing considerably since early 1990s due to the various liberalization policies of government of India. Indian manufacturers have started facing intense competition from Indian as well as from global manufacturers. This new competitive environment has forced the Indian manufacturers to think about the linking of manufacturing strategy with the overall business strategy. But, very little academic research has been reported in this area especially by the techno-managers of our country. All these have motivated the present researchers to venture

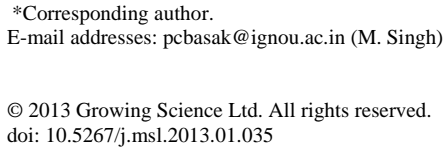


into this field. Hence, an attempt has been made to study the status of manufacturing strategy in three important Indian manufacturing sectors viz. Automobile, Tractor and General Manufacturing.

The manufacturing strategy specifies how the firm will align and deploy its production resources to support its corporate strategy. Similarly, the marketing strategy addresses how the firm will sell and distribute its goods and services, and financial strategy identifies how best to utilize the firm's financial resources. Manufacturing management decisions at the strategic level have profound impact on the company's long-range effectiveness in terms of how it can address its customer's needs in competitive business environment. Thus, for the firm to succeed, these decisions must be in alignment with the corporate strategy like marketing and finance. Manufacturing management is a functional field of business with clear line management responsibilities. This point is important because manufacturing management is frequently confused with manufacturing research and management science and industrial engineering. Fig. 1 shows the manufacturing management adopted in Indian manufacturing organizations.

A review of the small and medium enterprises (SME) sector of India gives some alarming signals. The signals do not come from simple performance-related experience. Rather, it is the shaky grounds which this sector is treading, in the wider context of globalization and liberalization. The term 'economic globalization' implies an evolving pattern of cross-border enterprise activities. It implies a change in the manufacturing business environment from pre-globalization to post globalization as mentioned below.

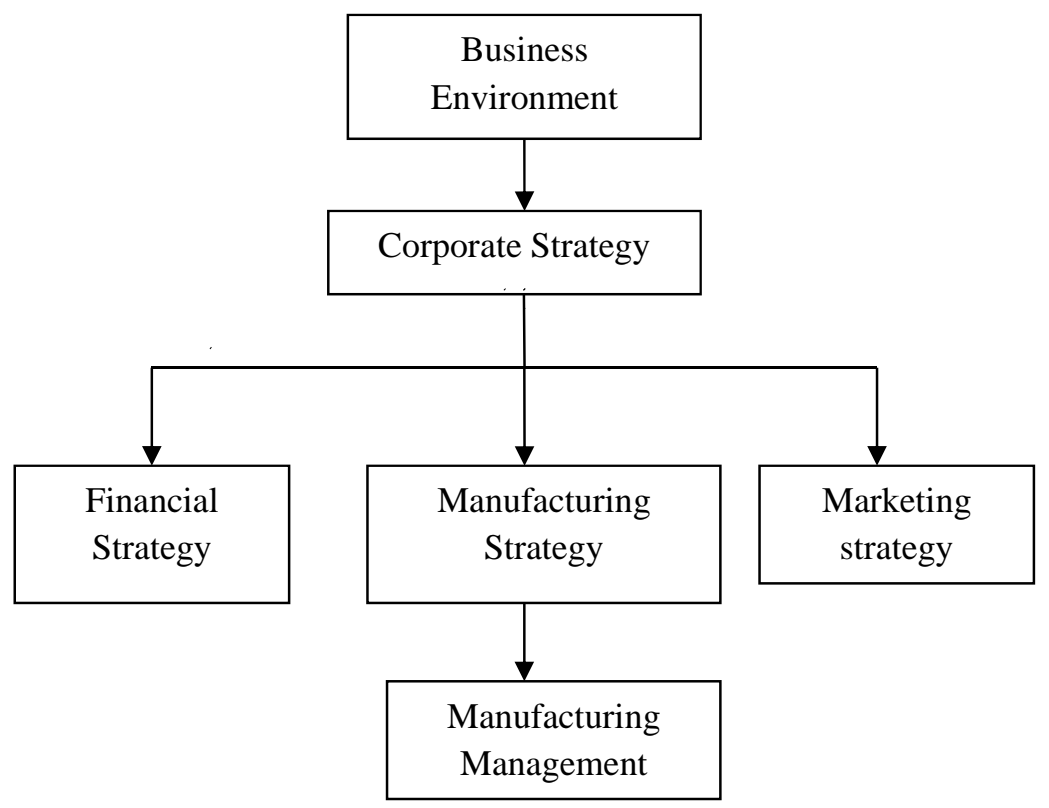

Fig. 1. Manufacturing management in organization

\section{Pre Globalization}

1) Local/National investment

2) Single-firm activity

3) Manufacturing for self-identified market

4) Local market

5) Rigid production system

6) Limited economic interest

\section{Post Globalization}

1) Collaborations

2) Strategic alliances

3) Outsourcing- local/ international

4) World market

5) Flexible production system

6) Focus on growth

The Global Competitiveness Report of 2009-10 published by the World Economic Forum, has ranked Switzerland as the world's most competitive nation, overtaking the USA. India was ranked at $49^{\text {th }}$ 
position amongst of the 133 major and emerging economies. India requires a different treatment as it presents the biggest contrasts as far as the social-indicators are concerned.

\section{Manufacturing strategy}

Skinner (1969) was the first to propose the concept of manufacturing strategy (MS). According to him "manufacturing strategy" refers to exploiting certain properties of the manufacturing function as a competitive weapon. He identified manufacturing function as the missing link in corporate strategic processes and emphasized that manufacturing can be converted as a formidable competitive weapon. According to Skinner, manufacturing can provide the sustainable competitive edge to an organization, if equipped and managed properly. Manufacturing function is central to the organization, because it produces the goods and services, which are its reason for existence. Manufacturing affects corporate strategy, and corporate strategy also affects manufacturing. He identified the shortsighted view of manufacturing in which, majority of top managers see it as requiring involved technical skills.

After Skinner's (1969) landmark article, manufacturing strategy has received lot of attention from various researchers. Hayes and Wheelwright (1984) have defined manufacturing strategy as a consistent pattern of decision making in the manufacturing function which is linked to the business strategy. Hill (1987) stated that manufacturing strategy represents a coordinated approach, which strives to achieve consistency between functional capabilities and policies for success in the marketplace. Swamidass and Newell (1987) defined manufacturing strategy as a tool for effective use of manufacturing strength as a competitive weapon for the achievement of business and corporate goals. Cox and Blackstone (1998) defined manufacturing strategy as "a collective pattern of decisions that acts upon the formulation and deployment of manufacturing resources. To be most effective, the manufacturing strategy should act in support of the overall strategic directions of the business and provide for competitive advantages". Hernandez et al. (2006) evaluates the use of decision support systems, software process modelling, expert systems, business process reengineering, simulation software, ABC cost manufacturing models and manufacturing databases methods and tools in order to propose general improvements in a manufacturing system and evaluate the implementation of new techniques. Du Jun et.al (2006) presented a practical method to assist the justification of a reconfigurable manufacturing systems in deciding how to influence its operating environment and choose right reconfiguration technologies in order to maximize the performance measure and profitability. Various researchers have also developed analytic models for linking process parameters optimally with various manufacturing objectives and thus influencing the strategic decision making process in the manufacturing area of the firm.

\subsection{Literature review}

The brief review of literature for manufacturing strategy with emphasis on various issues has been presented in two separate parts: (a) survey in various countries viz. USA, Japan and Europe and (b) survey in Indian manufacturing industries.

\subsubsection{Literature Review Globally}

Professor Skinner (1969) of Harvard Business School was first to recognize that manufacturing is the missing link in corporate strategy. He observed that many senior managers were delegating policy decisions to manufacturing that could have strategic consequences on competitiveness of the firm as a whole. The volume of literature on manufacturing strategy has increased gradually since the mid 1980s where, among others, Hayes and Wheelwright (1984) made a profoundly important contribution to the literature by mapping how manufacturing strategy linked with business strategy. Richardson et al., (1985), used the concept of manufacturing mission and manufacturing task. Fine 
and Hax, (1985), underscored the importance of coordinating the operations strategy with other functional and corporate-level strategies. Even when operations management is cited as a distinctive area in mainstream of manufacturing strategy literature, its role is often not seen as a strategic one and it is one which is positioned very tightly within a broader concern (Porter, 1986). Schroeder et al., (1986), studied how manufacturing strategy is defined in practice, touching on methods by which to identify strategies and the content elements of manufacturing strategies. Hayes and Wheelwright, (1984); De Meyer and Ferdows, (1987); Hill, (1993), have used Skinner's work as a starting point, adding competitive dimensions such as cost, quality, dependability and flexibility. The term manufacturing strategy is noticeable by its absence in mainstream literature on strategy and the role and purpose of manufacturing strategy remains a mystery for some firms (Hayes and Wheelwright 1984, Clark and Hayes, 1988; Brown, 1998). The perfect interrelationship between manufacturing strategy and corporate strategy is yet to be delineated properly (Spina, 1998). Pearce and Robinson (1988), Goodman and Lawless (1994), Acur and Bititci (2000), and Kaplan and Norton (2001), observed that people can only commit to a strategy if they believe in it. And in order to believe in a strategy, people must be convinced that they will achieve their goals as a result of pursuing this strategy. Pandza et al. (2005) discussed the role of advanced manufacturing technology (AMT) within a strategic management context of a manufacturing organisation.

US manufacturing futures survey (USMFS) was initiated in 1981 by the researchers of Boston University with the purpose of developing a comprehensive data set that can be used to study the strategic aspects of manufacturing management. The survey has been continuously refined in order to improve its relevance. Many other researchers conducted surveys in various part of USA (Schmenner, 1982; Jaikumar, 1986; Swamidass \& Newell, 1987; McDougall et al., 1992; Swamidass \& Kotha, 1998; Vickery et al., 1999; Pagell \& Krause, 1999, McDermott \& Stock, 1999; Li \& Ye, 1999; Kathuria, 2000; Ward \& Duray, 2000; Safizadeh et al., 2000; Pagel I \& Handfield, 2000; Kathuria \& Davis, 2001). Roberto Álvarez et al. (2009) focused on the redesign of operations by eliminating non value-added time and decreasing the intermediate stocks through Value Stream Mapping to identify improvement points and kanban and milk run to eliminate inefficiencies. Größler Andreas (2010) study shows that manufacturing firms in emerging markets have caught up with their counterparts from developed markets with regard to strategic capabilities in the groups of companies try to increase all four manufacturing capabilities in a similar fashion, with the emerging market group showing higher increase rates. Brousseau and Eldukhri (2011) introduces a European vision of the essential research areas to deliver future innovations in manufacturing. In particular, these areas are identified as Advanced Production Machines. David O’Sullivan et al. (2011) reiterate that high-tech manufacturing will continue to be a major player in the landscape of developed economies and how they receive these skills will need to change.

Similar surveys have been conducted by researchers in other parts of the globe such as European manufacturing futures survey (EMFS: Ferdows et al., 1986; Ferdows \& Lindberg, 1987; DeMeyer \& Ferdows, 1987; DeMeyer et al. 1989; Ferdows \& DeMeyer, 1990; DeMeyer \& Ferdows, 1990; DeMeyer \& Ferdows, 1991), World Class Manufacturing Project (WCMP: Flynn et al., 1997 \& 1999), International Manufacturing Strategy Survey (IMSS: Voss \& Blackmon, 1998; Cagliano \& Spina, 2000), Swedish Manufacturing Futures Survey (SMFS: Horte et al.,1987; Lindberg, 1990; Tunalv, 1990; Lindberg \& Trygg, 1991), Survey on Business Operations in Singapore (Ward et al., 1995), Survey of Spanish Manufacturing Companies (Correa, 1998), Survey on Hungarian Industry (Chikan \& Demeter, 1995), Survey of Israel Industry (Ragowsky \& Adams, 1998), Japan Manufacturing Futures Survey (Mortia \& Flynn, 1997), Survey of UK Companies (Neely et al., 1994; Burcher \& Lee, 2000; Beach et al., 2000), Survey of Italian Companies (Braglia \& Petroni, 2000; Cagliano \& Spina, 2000), Survey of Chinese Companies (Li, 2000), and Survey of UAE Companies (Badri et al., 2000). In the past two decades, the concept of manufacturing strategy has received increasing attention from researchers and the operations managers. As evidenced by the literature, numerous works have been reported on manufacturing strategy in different countries across the globe. 
In spite of this renewed interest in manufacturing strategy still has to go a long way to provide a reasonable impact on the literature mainstream strategy.

\subsubsection{Literature Review in Indian Context}

In Indian scenario the few studies on manufacturing strategy have been reported (Mohanty \& Deshmukh 1997; Chandra \& Sastry 1998; Sharma \& Upadhayaya, 1998; Nagabhushana \& Shah, 1999; Yadav et al., 1999; Mohanty \& Deshmukh 1999; Sexena \& Sahay 2000; Korgaonker, 2000, Dangayach \& Deshmukh, 2000, 2001, 2003). Mohanty and Deshmukh (1997) suggested a model of manufacturing strategy based on group decision support and learning organization. Chandra and Sastry (1998) reported in their survey of manufacturing Industries that Indian firms are competing on quality. No attention has so far been paid to the identification of improvement plans. They observed that the focus of Indian firm is on the competitive priorities. Sharma and Upadhayay (1998) studied manufacturing strategy issues in 20 manufacturing Industries. They prescriptively categorized manufacturing strategy of these industries in six categories such as rational, rational and interaction, rational and bold, interaction, interaction and bold, and bold and attempted to relate processes of manufacturing strategy making to its contents. The sample size was very small in their survey. Nagabhushana and Shah (1999) have identified manufacturing priorities and action programs in their study of thirty eight manufacturing industries from the electronics and machine tool sector. They did not mention the linkages of manufacturing priorities and action programs with manufacturing strategy. Yadav et al. (1999) describe the level of competence in 80 manufacturing firms, but there is no mention about other issues like human resource etc.

Mohanty and Deshmukh (1999) studied the various issues of manufacturing strategy in learning organization. Dangauach and Deshmukh (2000) observed manufacturing strategy practices in different companies from automotive and electronics sector. Sexena and Sahay (2000) observed that most Indian companies have fragmented integrated information systems. It means that Indian companies are not investing much in integrated information systems. Korgaonker (2000) reported that most Indian companies invest in Advance Manufacturing Technology, but nothing is mentioned about other improvement activities and their linkages with manufacturing strategy. Dangauach and Deshmukh (2001) studied process industries situated all over country and concluded that Indian process companies are investing in advanced management systems to manage the competition. Dangauach and Deshmukh (2003) studied the various factor of manufacturing in the Indian industries situated all over country. Thakur \& Jain (2008) explores the issues of measurement and comparison of the current state of advanced manufacturing technology (AMT) adoption in India, including important information technology (IT) factors. S. Vinodh et al (2009) study revealed that CADOE (computer aided design \& design of experiment) would facilitate time compression and enhance accuracy, which are the major enablers of achieving Agile Manufacturing.

\subsection{Indian manufacturing industry}

Manufacturing industry is made up of many different sectors. The performance of each sector is influenced by the prevailing overall-manufacturing climate of the country. From the Indian perspective, automobile, tractor \& general manufacturing industries, are considered to be very important sectors

\subsubsection{Automobile Industry (Two-Wheeler)}

The Indian two-wheeler industry made a small beginning in the early 1950s when Automobile Products of India (API) started manufacturing scooters in the country. Until 1958, API and Enfield were the sole producers. In 1960, Bajaj Auto set up a plant for manufacturing scooter in technical collaboration with Piaggio of Italy. The 50s, 60s and 70s were uneventful years of government 
regulation, prohibited new entries and strictly controlled capacity expansion. The two-wheeler market was opened to foreign competition in the mid-80s

Two-wheelers were one of the best performing industry segments in an otherwise sluggish economy in 2005-06. This unprecedented growth was fuelled by motorcycles. Further, they have demonstrated that Indian manufacturers have the capability to develop new vehicles without any external collaboration. They have also reaffirmed the fact that domestic design and engineering skills were being honed by the local partner even though the joint venture route was adopted in the past for sourcing technology from overseas automobile giants like Suzuki, Honda and Kawasaki.

\subsubsection{Tractors Industry}

After three years of decline, the light at the end of the tunnel seems much closer. The tractor industry's performance in the current financial year has shown a growth of 43 per cent over last year on the domestic front and a substantial increase in exports, according to the Tractor Manufacturers Association figures. The growth in domestic sales has been seen across various companies in India with Mahindra \& Mahindra, Tractors and Farm Equipment, Escorts and International Tractors recording growth above the industry average. After the decline in 2006-07, the recovery has been quite encouraging (The Hindu Survey of Indian Industry, 2006-07). Two major reasons attributed for the pick-up in tractor sales are the good monsoon and the emphasis on growth of the agricultural sector by the new government

\subsubsection{General manufacturing Industry}

In general manufacturing industry which is manufacturing the engine parts, machine parts, agrimachinary etc., lead-time plays an important role. Now due to an easy import policy of the government of India, a customer doesn't want to wait for longer time. Better quality machine tools are available at competitive prices in a shorter time from foreign competitors. This situation has forced the indigenous manufacturers to pay more attention to this sector. Indian machinery is a major source of inputs for the country's defense, railways, and infrastructural requirements as well. In terms of value of output, the industry may be contributing no more than $1 \%$ to the national Gross Domestic Product. However, the technology is still shy of the high speeds and robotisation that characterize the machines from advanced countries. But this also has to do with the fact that Indian users are not demanding such state-of-the-art machines. However, it is in the area of special purpose machines that the Indian machine tool industry is especially competitive since such machines need considerable design and custom engineering inputs which are much less expensive in India than in the West. The Indian general manufacturing industries has a large number of SMEs (small and medium enterprises). Almost all the industries of small and medium enterprises come under this category. The scope of this type of industries is very vast but in this study the main concern is on the type of industries of general goods from AC's, gears, tools condensers, gaskets etc. SME sector has around 2.60 crore units in India, contributing $45 \%$ to country's manufacturing output and $40 \%$ to exports. Major constraints on SMEs in meeting the challenges of competitiveness are:

i) Inadequate technologies as well as other resources.

ii) Excessive cost of product development projects

iii) Lack of effective selling techniques and market research

iv) Unable to meet the demand for multiple technological competencies.

v) Information gap between marketing and production functions as well as lack of funds for implementing expensive software such as ERP.

In order to improve the competitiveness of manufacturing sector, the programme suggested by the National Manufacturing Competitiveness Committee will have to be implemented in the right earnest with the cooperation of Industries Associations, technical bodies and all other stake holders. The 
growth of manufacturing sector is desirable for the larger benefits of the national economy and therefore policy interventions are essential. In order to ensure the sustained growth of manufacturing, sustained flow of affordable credit to this sector is required. A holistic approach needs to be followed that could address the demand and supply side issues of the manufacturing sector.

\subsection{Research methodology}

The research methodology is based on empirical data collected through a questionnaire survey. The main objective of this survey is to examine the status of manufacturing strategy issues in Indian manufacturing companies. The questionnaire was administered in 110 manufacturing companies from three major sectors i.e. automobile, tractor and general manufacturing industries in the northern India. The manufacturing strategy issues are Competitive Priorities, Improvement Activities, Manufacturing Competence (MC) and Business Performance (BP).

A database of 110 companies had been created and a structured questionnaire was administered. These companies were pooled in from the database of industrial directories and located mostly in northern India. Selection criterion was based on two parameters i.e. number of employees (more than 100) and annual sales (more than Rs.1.25 crore). After reminders, phone calls, e-mails and rereminders, 44 filled responses have been received, which gives response rate of $40 \%$. Out of the 44 respondents, 25 (57\%) were from the top management level i.e. CEO/ President /General Manager having 20 to 30 year experiences. Vital statistics of respondents is given in Table 1.

Table 1

Vital statistics of survey

\begin{tabular}{ccc}
\hline Industry sector & Questionnaire sent & Responses received (\%) \\
\hline Automobile & 40 & $17(43)$ \\
Tractor & 25 & $10(40)$ \\
General & 45 & $17(38)$ \\
Total & 110 & $44(40)$ \\
\hline
\end{tabular}

\subsection{Discussion and results}

The responses from the survey are analyzed for various structural and infrastructural issues of manufacturing strategy. These incorporate issues such as competitive priorities (quality, cost, delivery, and flexibility) improvement activities (AMT, IIS, and AMS), manufacturing competence index, and business performance index. Sector specific competitive priorities are studied in the Indian context. The priorities for Indian manufacturing companies belong to three sectors are given in Table 2. It has been observed from the table that Indian manufacturing companies are highly emphasizing on quality and the least on flexibility. A set of improvement activities for specific sector company are identified. Improvement activities are action plans in which a company invests to improve upon its structure and infrastructure. A company selects the improvement activities in order to build the manufacturing capabilities required by the market. It has been observed from the surveyed companies that Indian companies are investing more in advanced management systems as compared to integrated information systems and advanced manufacturing technology.

Table 3 depicts the importance of various improvement activities to the three important sectors of Indian manufacturing companies. The top three improvement activities of the Indian companies are Total Quality Management (AMS), Computer Aided Design (AMT), and Just-in-Time (AMS) and the three least preferred improvement activities are Robotics (AMT), Automated Guided Vehicles (AMT) and Cellular Manufacturing (AMT). It seems that Indian companies follow SIA approach i.e. Simplify (AMS) -Integrate (IIS) -Automate (AMT). 
Table 2

Top five competitive priorities

\begin{tabular}{llll}
\hline Sr.No. & Automobile & Tractor & General \\
\hline 1 & Conformance quality & Product durability & Delivery Speed \\
2 & Low cost & Product reliability & Conformance quality \\
3 & Product performance & Product performance & Low cost \\
4 & Product reliability & Conformance quality & Product performance \\
5 & Product durability & Delivery Speed & Product mix change \\
\hline
\end{tabular}

Table 3

Top Five Improvement Activities

\begin{tabular}{llll}
\hline Sr.No. & Automobile & Tractor & General \\
\hline 1 & Computer Aided Process Planning (AMT) & Total quality management (AMS) & Total quality management (AMS) \\
2 & Statistical Process Control (AMS) & Computer aided design (AMT) & Just-in-time (AMS) \\
3 & Computer Aided Engineering (AMT) & Computer Numerical Control (AMT) & Office automation (AMS) \\
4 & Total quality management (AMS) & Computer Aided Engineering (AMT) & Computer aided design (AMT) \\
5 & Computer aided design (AMT) & Office automation (AMS) & Business process reengineering (AMS) \\
\hline
\end{tabular}

In this research paper an attempt has also been made to measure Manufacturing Competence and Business Performance of Indian companies. Competitive Priorities (CP), Advanced Manufacturing Technology (AMT), Integrated Information Systems (IIS), and Advanced Management Systems (AMS) are used as four performance measures for manufacturing competence (MC), whereas Manufacturing Competence Index (MCI) and Business Performance Index (BPI) is calculated for each responded company.

Table 4 shows that emphasis on competitive priorities (CP) and Improvement Activities (IA) are significantly correlated, but Table 5 shows that competitive priorities are either low or negative correlated with business performance measures. This may be due to the fact that the Indian manufacturing firms invest less in advanced manufacturing technology (AMT) as mentioned earlier. This AMT eventually establishes the long term manufacturing competence that in turn helps to boost up the business performance. The AMT creates the manufacturing structure over which the desirable superstructure can be developed with the help of AMS and IIS. This lapse on the part of Indian manufacturing organization may be the basic reason for poor correlation between competitive priorities and business performance.

\section{Table 4}

Descriptive statistics and correlation for Manufacturing Competence

\begin{tabular}{|c|c|c|c|c|c|c|}
\hline \multirow[t]{2}{*}{ Item } & \multirow[t]{2}{*}{ Mean } & \multirow[t]{2}{*}{ Standard deviation } & \multicolumn{4}{|c|}{ Correlation } \\
\hline & & & $\mathrm{X} 1$ & $\mathrm{X} 2$ & X3 & $\mathrm{X} 4$ \\
\hline X1 (CP) & 3.98 & 0.632 & 1.000 & & & \\
\hline X2 (AMT) & 2.75 & 1.034 & $.517 * *$ & 1.000 & & \\
\hline X3 (IIS) & 3.01 & 1.060 & $.517 * *$ &. $.660 * *$ & 1.000 & \\
\hline X4 (AMS) & 3.24 & 0.777 & $.415^{*}$ & $.762 * *$ & $.574 * *$ & 1.000 \\
\hline
\end{tabular}

Table 5

Correlation for Manufacturing Competence and Business Performance

\begin{tabular}{|c|c|c|c|c|}
\hline \multirow[t]{2}{*}{ Item } & \multicolumn{4}{|c|}{ Correlation with } \\
\hline & $\mathrm{X} 1$ (CP) & X2 (AMT) & X3 (IIS) & X4 (AMS) \\
\hline Y1 (ROI) & .158 & -.079 & -.044 & -.245 \\
\hline Y2 (AS) & .239 & .059 & .227 & -.056 \\
\hline Y3 (TVA) & .316 & .066 & .227 & .053 \\
\hline Y4 (MS) & .288 & .046 & .259 & -.057 \\
\hline Y5 (EPS) & .171 & .273 & .306 & .120 \\
\hline
\end{tabular}


It is observed that the correlation between manufacturing competence and business performance is not significant. Sector wise correlations between MCI and BPI are also computed. It may be observed that

- There is a statistically significant correlation between MCI and BPI in overall.

- But, there is no correlation between MCI and BPI between various sectors companies

The average MCI of Automobile, Tractor, and General Manufacturing industry manufacturing sector companies is $1.573,1.644$ and 1.748 respectively.

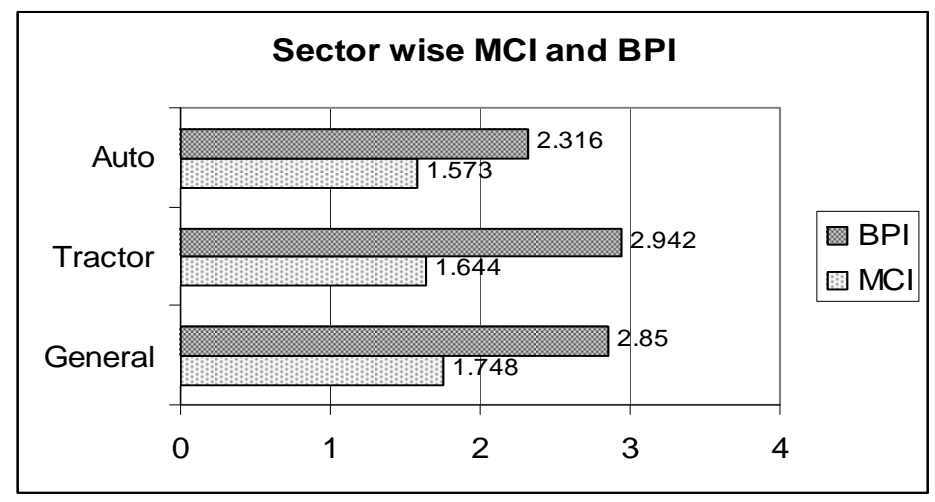

Fig. 2. Section wise MCI and BPI

From this, we can observe that general manufacturing sector companies is having greater value of MCI than that of other two sectors. These values are quantitative indication of the relative position of each sector on the manufacturing competitiveness. The average BPI of Automobile, Tractor, and general manufacturing industry sector companies are 2.316, 2.942 and 2.85 respectively. Sector wise average MCI and BPI is plotted and presented in Fig. 2. The performance indicators have the objective of evaluating whether the strategy is making the company to achieve the goal defined.

\section{Conclusion}

In this paper, the responses from the survey are analyzed for various structural and infrastructural issues of manufacturing strategy. These incorporate issues are competitive priorities (quality, cost, delivery, and flexibility) improvement activities (AMT, IIS, and AMS), and Business Performance. The present paper has attempted to explore these various issues related to manufacturing strategy in the Indian context. It is observed that the Indian manufacturing companies are emphasizing more on quality and the least on flexibility. It seems that Indian companies follow a progressive path to achieve competitive advantage i.e. quality to cost to delivery to flexibility. The analysis indicates that Indian companies are investing in improvement activities i.e. advanced manufacturing technology (AMT), integrated information systems (IIS), and advanced management systems (AMS) in ascending order. It is observed that Indian companies are investing more in AMS as compared to IIS and AMT.

It has observed from the case studies that there is an urgent need for the Indian firm to evolve the manufacturing strategy framework for its survival in the domestic competition provided by the both Indian as well as foreign multinational firms. Manufacturing strategy is not limited to a few key decisions about technology, capacity; but it is defined by the total pattern of decisions across the full spectrum of manufacturing systems. Manufacturing strategy is a tool for effective use of manufacturing strength as a competitive weapon for the achievement of business and corporate goals. India has a great potential to play a significant role in this new strategy of manufacturing business. 
The crucial factor for the success depends upon the abilities of the firms to link manufacturing strategy with the corporate business strategy through the achievements on various manufacturing performance objectives. Manufacturing strategy concept is addressed directly toward providing a strategic framework in manufacturing into which the individual decisions about various improvement activities such as AMS, IIS, and AMT can be properly addressed.

\section{References}

Acur, N., Gertsen, F., Hongyi, S., \& Frick, J. (2003). The formalization of manufacturing strategy and its influence on the relationship between competitive objectives, improvement goals, and action plans. International Journal of Operations \& Production Management, 23(10), 1114-1141.

Ahuja, I.P.S., \& Khamba, J.S. (2008). Review and Case Studies: Strategies and success factors for overcoming challenges in TPM implementation in Indian manufacturing industries. Journal of Quality in Maintenance Engineering, 14(2), 123-147.

Alvarez R., Calvo R., Marta, P.M., \& Domingo, R. (2009). Redesigning an assembly line through lean manufacturing tools. International Journals of Advanced Manufacturing Technology, 43, 949-958.

Anand, G., \& Ward, P.T. (2004). Fit, flexibility and performance in manufacturing: coping with dynamic environments. Production and Operations Management, 13(4), 369-385.

Aranda, A. (2003). Service operations strategy, flexibility and performance in engineering consultants firms. International Journal of Operations \& Production Management, 23(12),1401-1421.

Bessant, J. (2003). The manufacturing strategy-capabilities links in mass customization and agile manufacturing- an exploratory study. International Journal of Operations and Production Management, 23(7), 707-730.

Bititci, U.S, Turner, T., \& Begemann, C. (2000). Dynamics of performance measurement systems, International Journal of Operations and Production Management, 20(6), 692-704.

Laugen, B. T., Acur, N., Boer, H., \& Frick, J. (2005). Best manufacturing practices: what do the bestperforming companies do?. International Journal of Operations \& Production Management, 25(2), 131-150.

Bourne, M., Neely, A., Mills, J., \& Platts, K. (2003). Implementing performance measurement systems: a literature review. International Journal of Business Performance Management, 5(1), 124.

Brousseau, E., \& Eldukhri E. (2011). Recent advances on key technologies for innovative manufacturing. Journal of Intelligent Manufacturing, 22, 675-691.

Brown, S. (1998). Manufacturing strategy, manufacturing seniority and plant performance in quality. International Journal of Operations and Production Management, 18(6), 565-587.

Brown, S. (2000). Manufacturing the future: strategic resonance for enlightened manufacturing. Pearson Education, UK

Brown, S., \& Blackmon, K. (2005). Linking manufacturing strategy to the strategy mainstream: the case for strategic resonance. Journal of Management Studies, 42(4), 793-815.

Chandra, P., \& Sastry, T. (1998). Competitiveness of Indian Manufacturing, Vikalpa, 23(3), 25-36.

Cox III, J.F., \& Blackstone, J.H., 1998, APICS Dictionary (9th edition), Falls Church, VA.

Dangayach, G.S., \& Deshmukh, S.G. (2000). Manufacturing strategy: experiences from select Indian organizations. Journal of Manufacturing Systems, 19(2),134-148.

Dangayach, G.S., \& Deshmukh, S.G. (2001). Implementation of manufacturing strategy: a select study of Indian process companies. Production Planning and Control, 12(1), 89-105.

Dangayach, G.S., \& Deshmukh, S.G. (2003). Evidence of Manufacturing Strategies in Indian industry: A survey. International Journal of Production Economic, 83, 279-298.

Du. J., Jiao Y., \& Jiao J. (2006). A real-option approach to flexibility planning in reconfigurable manufacturing systems. International Journals of Advanced Manufacturing Technology, 28, 12021210. 
Fine, C.H., \& Hax, A.C. (1985). Manufacturing strategy: a methodology and an illustration, Interfaces, 15(6), 28-46.

Garvin, D.A. (1987). Competing on the eight dimensions of quality. Harvard Business Review, 65(6), 104-108.

Grobler A. (2010). The development of strategic manufacturing capabilities in emerging and developed markets. Operation Management Review, 3, 60-67.

Grobler, A., \& Grubner, A. (2006). An empirical model of the relationships between manufacturing capabilities. International Journal of Operations \& Production Management, 26(5), 458-485.

Hayes, R.H., \& Wheelwright, S.C. (1984). Restoring our competitive edge, competing through manufacturing. John Wiley and Sons, NY, 3-24.

Hernandez-Matias J. C., Vizan A., Hidalgo A. and Rios J. (2006). Evaluation of techniques for manufacturing process analysis. Journal of Intelligent Manufacturing, 17, 571-583.

Hill T.J. (1993). Manufacturing Strategy, $2^{\text {nd }}$ Ed., Macmillan, London

Joshi, M.P., Kathuria, R., \& Porth, S.J. (2003). Alignment of strategic priorities and performance: an integration of operations and strategic management performance. Journal of Operations Management, 21, 353-69.

Korgaonker, M.G. (2000). Competitiveness of Indian manufacturing enterprises. Manufacturing Magazine, December, 26-36.

Laugen, B.T., Acur, N., Boer, H., \& Frick, J. (2005). Best manufacturing practices: what do the bestperforming companies do? International Journal of Operations \& Production Management, 25(2), 131-150.

Mohanty, R.P. (2000). Value innovation perspectives in Indian organizations. South Asian Journal of Management, 6(2), 1-11.

Mohanty, R.P., \& Deshmukh, S.G. (1997). Manufacturing strategy evaluation for a learning organization: a case. The TMTC Journal of Management, 7(2), 23-43.

Mohanty, R.P., \& Deshmukh, S.G. (1998). Managing green productivity: some strategic directions. Production Planning and Control, 9(7), 624-633.

Mohanty, R.P., \& Deshmukh, S.G. (1999). Evaluating manufacturing strategy for a learning organization: a case. International Journal of Operations and Production Management, 19(3), 308

Nagabhushana, T.S., \& Shah, J. (1999). Manufacturing priorities and action programs in the changing environment: an empirical study of Indian industries. International Journal of Operations and Production Management, 19(4), 389-398.

Neely, A. (2005). The evolution of performance measurement research developments in the last decade and a research agenda for the next. International Journal of Operations \& Production Management, 25(12), 1264-1277.

Pandza, K., Polajnar, A., \& Buchmeister, B. (2005). Strategic management of advanced manufacturing technology. The International Journal of Advanced Manufacturing Technology, 25(3), 402-408.

Porter, M.E. (1986). Competitive Strategy. Harvard Business School Press, USA.

Porter, M.E. (1996). What is strategy. Harvard Business Review, 74(6), 61-78.

Porter, M.E., \& Miller, V. (1985). How information gives you competitive advantage. Harvard Business Review, 63(4), 149-160.

Cagliano, R., Acur, N., \& Boer, H. (2005). Patterns of change in manufacturing strategy configurations. International Journal of Operations \& Production Management, 25(7), 701-718.

Ramchandran, J., \& Sehrawat, S. (1999). The Indian two wheeler industries. South Asian Journal of Management, 5(2), 1-23.

Rangrajan, C. (2000). Economic reforms in India: some issues and concerns. Asian Economic Review, August, 1-5.

Roth, A. V. (1996), Achieving strategic agility through economies of knowledge. Strategy and Leadership (formerly Planning Review), 24(2), 30-37. 
Roth, A. V. (1996). Competitive progression theory: explanation and empirical evidence, in Manufacturing Strategy: Operations Strategy in a Global Context, (C. Voss, Ed.). London Business School, 309-314.

Roth, A. V., \& Giffi, C. A. (1994). Critical factors for achieving world class manufacturing. Operations Management Review, 10(2), 1-29.

Sethi, A.K., \& SETHI, S.P. (1990). Flexibility in manufacturing: a survey. International Journal of Flexible Manufacturing Systems, 2(4), 289-328.

Saxena, KBC, \& Sahay, B.S. (2000). Managing IT for WCM: the Indian scenario. International Journal of Information Management, 20, 29-57.

Sharma, R.R.K., \& Upadhyay, S. (1998). Manufacturing strategy: relating process and contents, Productivity, 39(2), 272-279.

Shrivastava, P. (1995). Environmental technologies and competitive advantage. Strategic Management Journal, 16, 183-200.

Singh, M., Basak, P.C., \& Singh, R. (2006). Manufacturing strategy for Indian corporate success. Productivity Promotion, 9(9), 4-11.

Singh, M., Singh, R., \& Basak, P.C. (2007). Manufacturing strategy issues in India in Globalize Era, Osmania. Journal of Management, 3(5), 152-164.

Singh, M., Basak, P.C., \& Singh R. (2009). Competitive factors and their relative importance in the Indian manufacturing industries. Journal of Asian Business Management, 1(1), 13-18.

Singh, M., Basak, P.C., \& Singh R. (2009). Strategic Management of manufacturing and some issues. Journal of Business Management, 1(1-2), 143-151.

Skinner, W. (1969). Manufacturing- missing link in corporate strategy. Harvard Business Review, 47(3), 136-144.

Spina, G. (1998). Manufacturing paradigms versus strategic approaches: a misleading contrast. International Journal of Operations and Production Management, 18(8), 684-709.

Sullivan O’ D., Rolstadas, A., \& Filos. E. (2011). Global education in manufacturing strategy. Journal of Intelligent Manufacturing, 22, 663-674.

Swamidass, P.M., \& Newell, W.T. (1987). Manufacturing strategy, environmental uncertainty and performance: a path analytic model. Management Science, 33(4), 509-524.

Thakur, L. S., \& Jain, V. K. (2008). Advanced manufacturing techniques and information technology adoption in India: A current perspective and some comparisons. The International Journal of Advanced Manufacturing Technology, 36(5), 618-631.

The Hindu Survey of Indian Industry. (2003-2004). The Hindu, Chennai.

The Hindu Survey of Indian Industry. (2004-2005). The Hindu, Chennai.

Toni, A., \& Tonchia, A. (2003). Strategic planning and firms competencies. International Journal of Operations and Production Management, 23(9), 947-976.

Upadhayay, A., \& Kanavi, S. (1999). The end of manufacturing. Business India, January 25February 7, 52-59.

Vinodh S., Sundararaj G., Devadasan S. R., Kuttalingam D., \& Rajanayagam D. (2009). Computeraided design of experiments: an enabler of agile manufacturing. International Journals of Advanced Manufacturing Technology, 44, 940-954

Yadav, O.P., Bhandari, R., \& Mohanty, R.P. (1999). Level of manufacturing competence in Indian companies: an analysis. Proc. of International Conference on Production and Operations Management POMS-99 (India) (Arun Kanda et al. Ed.), Phoneix Publishers, New Delhi, 3-22. 